\title{
Building capacity for local government to perform
}

\author{
Commonwealth Journal of Local Governance \\ Issue 6: July 2010 \\ http://epress.lib.uts.edu.au/ojs/index.php/cjlg
}

\section{Ronald McGill ${ }^{1}$}

Ministry of Finance and Economic

Development

Addis Ababa, Ethiopia

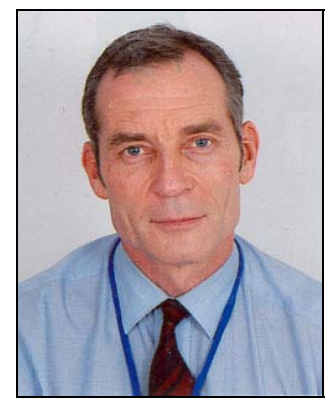

\section{Introduction}

This paper looks at the practitioner's challenge of building capacity for local government to perform. It does so by ways of responding to some of the policy recommendations put forward at the Commonwealth Local Government Conference (CLGC) held in the Bahamas in May 2009.

It is suggested that capacity building in local government, particularly in the least developed countries (LDCs), ${ }^{2}$ is riddled with rhetoric. There is no common reference point for the concept. The following text is therefore drawn from practice: that of a local government practitioner - the author - with experience in diverse countries (Scotland, England, Malawi and Tanzania), and of an organization wedded to the fundamental importance of local government to local development, ${ }^{3}$ and with sound understanding of capacity building interventions - the United Nations Capital Development Fund (UNCDF).

\footnotetext{
1 The author was a senior technical adviser with the United Nations Capital Development Fund (UNCDF) in New York from 2001 to 2009. He is now the program budget adviser to Ethiopia's finance ministry.

${ }^{2}$ http://www.un.org/esa/policy/devplan/profile/index.html

3 http://www.uncdf.org/english/local_development
} 
The capacity building challenge is summarized in Table 1. It is argued that the five elements of this challenge, explained below, represent the building blocks for local government's successful performance. They are the fundamental interventions to allow higher-order policy decisions to gain purchase within the local government system.

Table 1: The challenge of building capacity

\begin{tabular}{|l|l|l|}
\hline & Main aspects of capacity building & Practical implications \\
\hline 1 & Institutional development & $\begin{array}{l}\text { The context, structure and processes to allow } \\
\text { functions to be performed }\end{array}$ \\
\hline 2 & $\begin{array}{l}\text { Measuring performance in providing } \\
\text { infrastructure and services }\end{array}$ & $\begin{array}{l}\text { The economy, efficiency and effectiveness of } \\
\text { delivery }\end{array}$ \\
\hline 3 & Getting local government to deliver & Minimum capacity thresholds \\
\hline 4 & Building blocks for building capacity & Capacity interventions \\
\hline 5 & Integrated service delivery system & $\begin{array}{l}\text { Understanding the pivotal role of local } \\
\text { government in local development }\end{array}$ \\
\hline
\end{tabular}

At the CLGC, working group number 5 generated five issues and responding recommendations. At a strategic level, the group's main concern was with Millenium Development Goal (MDG) indicator number 12: "the proportion of seats held by women in national parliament”. The group lamented that there was no equivalent indicator for women's political representation in local government. For the participants, this suggested a lack of understanding of and belief in local government at the very highest level of policy debate in international development. This conclusion was therefore the springboard for five policy-based recommendations:

1) MDG-3's indicator number 12 reads: Proportion of seats held by women in national parliament. ISSUE - there is no reference to political representation at the local government level. RECOMMENDATION: That local government's political representation be targeted at a minimum of $30 \%$ of all seats/wards by women and by a figure exceeding that percentage, as soon as possible. This was and is a most obvious policy intervention at the global level. It makes a modest but crucial change to the MDG indicators so that local government is given due recognition in the first place. Secondly, women would then be given the space (and domestic support) to be active members in the local development process through the political and administrative machinery of local government itself. 
2) ISSUE - Implementation capacity is a bane of local government, especially when development funds actually become available. RECOMMENDATION: That all local government development projects be subject to an initial assessment, to include explicit capacity-building elements, in the fundamental areas of planning, budgeting, procurement, construction management, and financial management (including accounting and auditing). This simply reinforces the last main section of this text; the 'binding address' of infrastructure and service delivery. The contention is that local government should be the location's local development agency, harnessing energy and resources from all sectors, both in formulating an integrated development plan and making spending decisions to support every 'player's' part of that plan (explained further in the last section of the paper).

3) ISSUE - There is a desperate shortage of engineers in developing countries; a key to success in local development practice. RECOMMENDATION: That national governments in developing countries increase their investment in the education of civil engineers by $50 \%$ and that scholarships be awarded to those willing to serve at least two years in a local council after graduation. Engineers, surveyors, architects and (urban and regional) planners are the professions most closely concerned with the local development process. In addition, planners have a tradition of advocating in favour of community-based involvement in the local development process. That cluster of capacity demands is explained further below.

4) ISSUE - It is often impossible to recruit professional and other staff to councils outside the main urban centres because of a lack of incentives such as the availability of housing for staff and education for their children. RECOMMENDATION: That national governments introduce a policy and provide supporting resources for councils classified as remote and not being able to attract staff, to provide housing and primary education, free, in these locations. How often has it been reported that central government staff members have been posted to outlying or remote regions and that they either go reluctantly or they resign; a loss to the public service? It should be within the scope and imagination of governments committed to local development, to recognise the need to build incentives for staff members to move. Free housing and education would seem the most basic incentives that a government could provide. For example, in Sierra Leone, one of the major obstacles to progress 
in decentralisation was that there was no housing and local education capacity to accommodate the envisaged staff numbers that would have to move to the UNCDF programme location of Kenema District; the focus of a decentralisation assessment, that scored a miserable $4 \%$ towards achieving the decentralisation of functions from central government to the district. Indeed, there was no formal system of planned housing plot provision, whether serviced or un-serviced. Land allocation was locked in the hands of the traditional leaders.

5) ISSUE - Councils often recognize potential sources of local revenue but are not permitted, in law, to raise such revenue. RECOMMENDATION: That national governments introduce or amend local government legislation to permit councils to raise such additional revenues as they deem possible and practical, subject to the appropriate council resolution and subsequent by-laws being passed. This is a case of attempting to remove two restrictions. One is the simple matter of unblocking the blockages to local government being able to show initiative and harness potential for additional revenue. The other is to stop central government 'clawing back' the identified additional local revenue by reducing its fiscal transfers by the same amount. If central government feels that strongly, it should develop a formula whereby local government retains the majority but agrees to transfer a portion of that additional revenue to the centre. Some argue that all local governments should be self-financing. This seems fanciful let alone inequitable, in that much of local government's expenditure generates the external economies for the private sector to be able to perform: roads, sanitation, water. Some regions will always be poorer so an equalisation dimension to central government fiscal transfer systems remains legitimate.

While these five policy recommendations are laudable, perhaps even crucial in themselves, the truth is that they can only work if the fundamentals of local government capacity building introduced in Table 1 are met. 


\section{Institutional development: the macro-perspective}

\section{Government reform}

In government reform, the agenda for change boils down to (a) an understanding of the current and desired functions of government, and (b) the translation of the these functions into the:

- Policy, legal and regulatory context

- Organisational structures, the deployment of personnel and their training needs

- Planning, budgeting, implementation and review processes, including their supporting information systems.

The shorthand for this is the institutional development (ID) agenda (1995a). The ID process to achieve locally understood and determined reform involves care in the facilitation of the change itself (McGill, 1999). The central point is that the ID agenda of context, structures and processes, to perform the functions, should be mutually inclusive. This optimises the potential for the economical, efficient and effective delivery of infrastructure and services. If one part of the agenda is 'out of step', it limits the potential for full performance from the particular institution being reformed. An example best illustrates this point.

In Malawi in 1989 to 1991, government was committed to transferring responsibility for the related functions of town planning and both housing development and management to the four city councils: Lilongwe, Blantyre, Mzuzu and Zomba. While part of the context (policy) was in place, the legal and regulatory framework was not. Legislation and supporting regulations therefore had to be drafted and approved by parliament. There was no structure (a department with trained personnel). This had to be created and staff recruited from scratch. While the process of town planning could be transferred from the Office of the President and Cabinet, there was no city-based manual to explain the development and management of housing areas, previously the responsibility of the Malawi Housing Corporation. The Municipal Development Program helped Lilongwe city council develop such a manual. In short the triumvirate of the institutional development agenda (of context, structures and processes) to perform the (to be) transferred functions had to be in place before the detailed questions of capacity could even be considered. These turned on the twin questions of local government performance and local government capacity to perform. 
The lesson here was that the 'form' of the institution (in this case, Lilongwe city council) needed to be determined by the 'functions' it was attempting to perform; the adage therefore being the familiar one of form follows function (McGill, 1997 and 1996). Thus, once the institutional framework of context, structures and processes is in place, one can drill down to the levels of practicality; local government performance, its capacity to perform, and the organisational building blocks required to establish that capacity.

\section{Performance: measuring local government delivery}

The demand for infrastructure and services confronts every local government in the developing world. The weakness of local government compounds the enormity of the challenge (McGill, 1997 and 1996). The fundamental importance of access to infrastructure and services, as a means of supporting both economic development and to impact on various parts of the poverty spectrum, is now accepted in common parlance. The key point is that we are seeking to establish 'what difference local government is making out there?' with the money it is spending. One method for measuring such delivery is through performance budgeting (McGill, Ed, 2006 and McGill, 2001a).

Performance budgeting (PB) is founded on the principle of delivering infrastructure and services, economically, efficiently and effectively; the 3-Es. This is the notion of value for money (VFM) in government (McGill, 1984). Each 3-Es measurement criterion is explained in turn.

\section{Economy of inputs}

Any organisation's leader knows that if you budget $\mathrm{X}$, you should spend $\mathrm{X}$ and that you should deliver what you promised. Variance analysis is the first technique in measuring the economy of inputs. Thus, if the item of infrastructure or the targeted service to be delivered costs 10,000 , the following is already assumed:

- That the budgeted figure is technically accurate

- It is based on experience (if service delivery, dominated by personnel costs) or an engineer's ‘bill of quantity' (if a capital project)

- It anticipates any cost fluctuations, say, because of the prospect of cost inflation. Thus, the first score in measuring PB performance is:

$$
\text { (1) = Economy of inputs (where } \mathrm{T}=100 \% \text { ) }
$$


Here, ' $\mathrm{T}$ ' is the target of $100 \%$. So, if the budget is 10,000 and the actual is 10,000 then we are on target; a score of $100 \%$. If at the end of the year, only 5,000 are spent, then the score is $50 \%$ and so on. The basic intellectual principle is that of common sense.

\section{Efficiency of outputs}

Any organisation's leader knows that if you budget to deliver outputs (a road, primary health care etc), it is that for which you are most obviously accountable. This is especially so if you have told the public that 'these are the things we intend to deliver next year'. In order not to drown PB in data, only two generic criteria are advocated for measuring the delivery of outputs. So, beyond the number (the target) to be achieved, these criteria are $\mathbf{A}=\%$ specification, and $\mathbf{B}=\%$ time.

If the output is through capital expenditure, then there is always a technical specification of what is to be constructed (a new school, the rehabilitation of X kilometres of road etc). If there are 20 items in the technical specification (the bill of quantities or 'BoQ'), all have to be satisfied. If all are satisfied, then the specification is fully satisfied, so $100 \%$ (divided by 2 because this is only half of the output measure).

The other half is of time. If the output is to be delivered in 60 days and it takes 60 days, you are on target. If more, then you are over-budget in terms of time and the score is less, accordingly. If the output is through recurrent expenditure, then the test is different. We have to define what standard of service is to be delivered. For example, in education, how many pupils should a teacher teach in the course of the year? In health, how many people should the health clinic be able to service, comfortably? In agriculture, what should the extension service be providing through routine events and when? Putting measures for recurrent expenditure is more difficult but again, for experienced practitioners, it really is a matter of applied common sense.

To assess on-time performance, a basic timetable for any particular service can be established. A school must provide three terms of schooling in a year: has this been achieved? In a clinic: has the service been available as intended? In agricultural extension: has the service been made available in accordance with the annually agreed timetable? Experienced practitioners also know that the output being delivered as part of any program is that which is directly attributable to the program's owner. Basic 
accountability is therefore assured. Thus, the second score in measuring PB performance is:

$$
\text { (2) }=(\mathrm{A}+\mathrm{B}) / 2=\text { Efficiency of outputs (where } \mathrm{T}=100 \% \text { ) }
$$

Here again, ' $\mathrm{T}$ ' is the target of $100 \%$. So, if the specification is fully satisfied and everything has been delivered according to time, then the score for each of A and B is $100 \%$, which is then divided by two, to give the aggregate score for that deliverable. Again though, the basic intellectual principle is that of common sense.

\section{Effectiveness of impact}

Any organisation's leader knows that the economy of inputs and the efficiency of outputs, ultimately, have no practical meaning if there is no effective impact. At the annual level, there are two basic criteria to measure this impact. These are:

$$
\begin{aligned}
& \mathbf{C}=\% \text { occupancy rate/use of facility } \\
& \mathbf{D}=\% \text { assessment of 'problem solved' }
\end{aligned}
$$

Whether delivered through capital or recurrent expenditure, the result of the asset created or the service delivered has to be in terms of a basic impact question: is the school or clinic satisfying the need? Is the new market being fully used? What is the 'bottom-line' here? Has the original problem been solved? Anyone in any community is able to define a problem to be solved. Equally, anyone is able to assess, from a user's perspective, if the problem has indeed been solved. Table 2 illustrates this issue of problem definition and suggests how to assess whether or not the problem has been addressed successfully. 
Table 2: Problem definition and 'raw' project proposal

\begin{tabular}{|l|l|l|l|}
\hline $\begin{array}{l}\text { Perceived } \\
\text { problem }\end{array}$ & Elements of the problem & $\begin{array}{l}\text { Project } \\
\text { response }\end{array}$ & Recurrent service and resourcing \\
\hline $\begin{array}{l}\text { No } \\
\text { education }\end{array}$ & $\begin{array}{l}\text { Nearest education 10 km away } \\
\text { 380 school-age children need the } \\
\text { service, hence viability of a new } \\
\text { school }\end{array}$ & $\begin{array}{l}\text { New school } \\
\text { building }\end{array}$ & $\begin{array}{l}\text { Teachers and supplies, through the } \\
\text { education ministry }\end{array}$ \\
\hline $\begin{array}{l}\text { No health } \\
\text { care }\end{array}$ & $\begin{array}{l}\text { Nearest clinic 10 km away } \\
\text { Malaria } \\
\text { No basic preventive health care }\end{array}$ & Health post & $\begin{array}{l}\text { Staff and medical supplies, co- } \\
\text { funded by health ministry and } \\
\text { community }\end{array}$ \\
\hline $\begin{array}{l}\text { Inadequate } \\
\text { water }\end{array}$ & $\begin{array}{l}\text { Nearest main source 7 km away } \\
\text { Shallow wells } \\
\text { No catchment systems }\end{array}$ & $\begin{array}{l}\text { Deeper wells } \\
\text { and catchment } \\
\text { terracing to } \\
\text { retain the water } \\
\text { table }\end{array}$ & $\begin{array}{l}\text { Maintenance of wells and catchment } \\
\text { locations, through community } \\
\text { initiatives }\end{array}$ \\
\hline $\begin{array}{l}\text { No vehicle } \\
\text { access in } \\
\text { bad } \\
\text { weather }\end{array}$ & $\begin{array}{l}\text { Seasonal problem } \\
\text { Flooding }\end{array}$ & $\begin{array}{l}\text { Culverts and } \\
\text { fords }\end{array}$ & $\begin{array}{l}\text { Regular maintenance through } \\
\text { community programmes }\end{array}$ \\
\hline No market & Nearest market 10 km away & $\begin{array}{l}\text { Area and basic } \\
\text { structures }\end{array}$ & $\begin{array}{l}\text { Maintenance through owner levies } \\
\text { and community supervision }\end{array}$ \\
\hline $\begin{array}{l}\text { Lack of } \\
\text { food }\end{array}$ & $\begin{array}{l}\text { Available fertile locations } \\
\text { Available underground water } \\
\text { sources }\end{array}$ & $\begin{array}{l}\text { Relate to } \\
\text { inadequate } \\
\text { water proposal) }\end{array}$ & N/a \\
\hline
\end{tabular}

It is at the level of 'effectiveness' that the client - the recipients of the service - are best placed to inform the providers of the new capital asset or the delivered service. So the question: 'has the problem been solved?' is answered by responding to the two righthand columns. Finally, experienced practitioners know that the output being delivered as part of any program must have a positive (i.e. a declared, desired) impact on those for whom the infrastructure or service is being delivered. This encourages public accountability. The third score in measuring PB performance is therefore:

$$
\text { (3) }=(C+D) / 2=\text { Effectiveness of impact (where } \mathrm{T}=100 \%)
$$

Again, ' $\mathrm{T}$ ' is the target of $100 \%$. So, if the customers are satisfied with the infrastructure or the service, then the score for $\mathrm{C}$ is $100 \%$. If the answer is 'yes' to the second question: 'has the original problem has been solved?', then again the score for D is $100 \%$. The combined score is also divided by two, to give the aggregate score for that output's impact. For fear of repetition, the basic intellectual principle is that of common sense.

\section{Total program performance measurement}

Total program performance is economy (1), efficiency (2) and effectiveness (3), divided by three, to give the final percentage score, as follows: 


$$
\mathbf{T}=(1+2+3) / 3=\text { Total performance }
$$

In this approach to PB performance, equal weight is given to the '3-Es'. An example again best illustrates the idea.

A donor offered the Malawi Government a new produce market for Lilongwe's capital city centre. The offer was welcomed, subject to the condition that the market was located in a land-use zone adjacent to the centre itself; the proposal being considered 'inappropriate' for the capital's new city centre! This was accepted, reluctantly. The market was built according to budget (the economy of inputs was satisfied). It was built to specification and to time (the efficiency of outputs was satisfied). However, the original problem (in truth, the opportunity) was not satisfied; the asset was not fully used. In fact, it was never more than 15\% used (the effectiveness of impact was not satisfied). Performance budgeting's measurement therefore gave the 'process of delivery' credit for being economical and efficient (both capacity tests in themselves), but there was little effectiveness; the expenditure made 'very little difference out there!' In short, PB measurement is holistic in the sense that it is concerned with both the process of delivery as well as the impact of its results.

If performance budgeting is accepted as a practical basis for measuring local government performance, then the next step is to establish tests for local government to be able to perform in the first place.

\section{Capacity: Enabling local government to deliver}

There are certain fundamentals that every local government should have, by way of capacity, to allow it to perform. Assuming for the moment a district council, then there should be:

- A current district development plan and budget

- A functioning district council and district administration

- A functioning financial management system

- The establishment of a local development fund (i.e. capital funds) account

- Key district staff in place.

Table 3 presents not only these five minimum conditions but also their capacity targets and weighting, for scoring. The argument is that in order to deliver (to 
perform), local government must have certain key prerequisites in place (and these items are, of course, an absolute minimum). One way or another, these capacity requirements cannot be achieved unless the building blocks themselves are put in place.

Table 3: Enabling local government to deliver

\begin{tabular}{|c|c|c|c|}
\hline $\begin{array}{l}\text { Minimum } \\
\text { conditions }\end{array}$ & Capacity Targets & $\begin{array}{c}\text { Percentage } \\
\text { weight }\end{array}$ & $\begin{array}{c}\text { Actual score } \\
\%\end{array}$ \\
\hline \multirow{2}{*}{$\begin{array}{l}\text { Existence of a } \\
\text { district development } \\
\text { plan and budget. } \\
\text { Max = } 20\end{array}$} & \multirow{2}{*}{$\begin{array}{ll}\text { - } & \text { Approved development plan, } \\
\text { through community participation } \\
\text { (3-5 years) } \\
\text { Approved annual budget to } \\
\text { implement that year's portion of the } \\
\text { plan }\end{array}$} & 10 & \\
\hline & & 10 & \\
\hline \multirow{3}{*}{$\begin{array}{l}\text { Functioning district } \\
\text { council and district } \\
\text { administration. } \\
\text { Max }=20\end{array}$} & \multirow{3}{*}{$\begin{array}{ll}\text { - } & \text { Full council and committee } \\
\text { meetings timetable honoured in full } \\
\text { - } & \text { Women's participation quota met } \\
\text { - } & \text { Accurate 'minutes' produced within } \\
\text { two weeks of any such meeting }\end{array}$} & 5 & \\
\hline & & 10 & \\
\hline & & 5 & \\
\hline \multirow{3}{*}{$\begin{array}{l}\text { Functioning } \\
\text { financial } \\
\text { management system. } \\
\text { Max = } 20\end{array}$} & \multirow{3}{*}{$\begin{array}{ll}\text { - } & \text { Daily accurate financial records by } \\
\text { CoB. } & \\
\text { Monthly bank reconciliations, } \\
\text { - } \\
\text { within two weeks of month-end } \\
\text { Quarterly financial reports within } \\
\text { two weeks of quarter end }\end{array}$} & 10 & \\
\hline & & 5 & \\
\hline & & 5 & \\
\hline $\begin{array}{l}\text { Establishment of a } \\
\text { local development } \\
\text { fund (i.e. capital } \\
\text { fund) account. } \\
\text { Max = } 10\end{array}$ & $\begin{array}{ll} & \text { Functional capital account }\end{array}$ & 10 & \\
\hline \multirow{4}{*}{$\begin{array}{l}\text { Key district staff in } \\
\text { place. } \\
\text { Max }=30\end{array}$} & \multirow{5}{*}{$\begin{array}{ll}\text { - } & \text { Administrator } \\
\text { - } & \text { Finance officer } \\
\text { - } & \text { Planner } \\
\text { - } & \text { Five technical supervisors } \\
& \text { (Education; Agriculture; Health; } \\
& \text { Women; Capacity) } \\
\end{array}$} & 5 & \\
\hline & & 5 & \\
\hline & & 5 & \\
\hline & & 15 & \\
\hline 100 & & 100 & \\
\hline
\end{tabular}

\section{Organisation: The building blocks for basic capacity}

It is recognised that no infrastructure and services can be delivered without people in local government. An immediate focus for intervention is therefore, to get people in place to do the work. Table 4 presents an example of a framework for assessing capacity. This happens to include measuring progress in applying gender equitable local development (GELD) principles (UNCDF 2008) in building a local authority. 
Table 4: The building blocks for basic capacity

\begin{tabular}{|c|c|c|c|c|c|c|c|}
\hline $\begin{array}{l}\text { Generic functions } \\
\text { of a district council }\end{array}$ & $\begin{array}{l}\text { Number of } \\
\text { posts required } \\
\text { (\% of women } \\
\text { according to } \\
\text { national } \\
\text { standards). } \\
\text { (See Note } 1 \text { ) }\end{array}$ & \begin{tabular}{|l|} 
Number of \\
posts \\
established (\% \\
of women \\
according to \\
national \\
standards) \\
(See Note 2)
\end{tabular} & \begin{tabular}{|l|} 
All \\
established \\
posts to \\
perform each \\
devolved \\
function filled \\
in the district? \\
(See Note 3)
\end{tabular} & \begin{tabular}{|l} 
All \\
established \\
personnel \\
fully trained \\
to perform the \\
devolved \\
functions? \\
(See Note 4)
\end{tabular} & \begin{tabular}{|l|} 
Facilities: \\
accommo- \\
dation (gender \\
sensitive, \\
including \\
hygiene \\
arrange- \\
ments), plus \\
furniture, \\
systems, \\
equipment \\
and transport \\
provided? \\
(See Note 5) \\
\end{tabular} & $\begin{array}{l}\text { Assessment of } \\
\text { productivity: } \\
\text { i.e. } \\
\text { performing } \\
\text { economically, } \\
\text { efficiently and } \\
\text { effectively in } \\
\text { the } \\
\text { performance } \\
\text { of the } \\
\text { function? (See } \\
\text { Note 6) }\end{array}$ & $\begin{array}{l}\text { Total score of } \\
\text { 'capacity to } \\
\text { perform the } \\
\text { function' } \\
\text { (including \% } \\
\text { of women } \\
\text { according to } \\
\text { national } \\
\text { standards)? } \\
\text { (See Note 7) }\end{array}$ \\
\hline & $\% \mathrm{n} / \mathrm{a}$ & $10 \%$ & $10 \%$ & $10 \%$ & $30 \%$ & $40 \%$ & $\mathrm{~T}=100 \%$ \\
\hline \multicolumn{8}{|c|}{ 'Line' Functions (those that do the actual delivery) } \\
\hline \multicolumn{8}{|c|}{\begin{tabular}{|l|l|l|}
$\begin{array}{l}\text { Education, Youth, } \\
\text { Sport and Culture }\end{array}$ & & \\
\end{tabular}} \\
\hline \multicolumn{8}{|l|}{$\begin{array}{l}\text { Health, Gender, } \\
\text { Family Promotion }\end{array}$} \\
\hline \multicolumn{8}{|l|}{$\begin{array}{l}\text { Economic } \\
\text { Development } \\
\end{array}$} \\
\hline \multicolumn{8}{|l|}{$\begin{array}{l}\text { Infrastructure, Land, } \\
\text { and Planning }\end{array}$} \\
\hline \multicolumn{8}{|c|}{ 'Staff' Functions (those that support the people that deliver, such as finance and human resources) } \\
\hline \multicolumn{8}{|l|}{$\begin{array}{l}\text { Administration and } \\
\text { Good Governance }\end{array}$} \\
\hline \multicolumn{8}{|l|}{\begin{tabular}{|l|} 
Financial \\
management, Human \\
resource development \\
and so on
\end{tabular}} \\
\hline \multicolumn{8}{|l|}{$\begin{array}{l}\text { Mayor and executive } \\
\text { or central policy } \\
\text { committee } \\
\end{array}$} \\
\hline Total Score & & & & & & & \\
\hline
\end{tabular}

\section{Notes from Table 4:}

1) The question to be asked is: how many people will be required to perform the specific service in the district? This has to include the question of the quota of women (ideally, the quota comes from the appropriate legislation). The answer to the number of people should be followed by a basic understanding of the 'level' of post or posts required, including any hierarchical relationship. Once the number of posts is known, assessing the 'measurable progress' can start.

2) If the estimate of the number of posts is accurate, the district will ensure that the 'authorised establishment' (i.e. the approved number of posts) is altered to accommodate the extra posts. This accommodation must include the quota for women.

3) The recruitment process is known to all. It must be open and transparent.

4) Whatever the minimum requirements to fill a post, it is often (but not always) necessary to provide training so that the new personnel are able to perform. Affirmative action, through additional training, may be required to ensure that the women recruited are able to perform as well as men.

5) 'Facilities' is so obvious, it should not need to be defined and yet, it is so often overlooked: office space, furniture, equipment and supplies. This is where sensitivity is required to support women's specific needs. These can include adequate sanitation 
facilities, personal safety, and child care where possible. Too often, people are blind to these gender-specific needs.

6) Performance is measured according to the principles of economy, efficiency and effectiveness.

7) The total score is the simple addition for each row because the weighted score can only add up to $100 \%$ maximum. The council's total score is then the addition of all rows, divided by the number of rows.

What we have here is the bottom line of capacity measurement, on the simple test of getting people in post to be able to perform. Yet, even this bottom line cannot deny the institutional development (ID) framework within which all capacity interventions will have to fit. If the ID framework is contorted or disjointed (e.g. the structure and processes are not aligned), then the capacity interventions are going to be less than efficient and effective.

\section{The 'binding address' of infrastructure and service delivery}

Capacity-building interventions are a means to an end and not an end in themselves. That end is the 'binding address' of local government's development planning, strategy and budgeting. This is the foundation for delivering infrastructure and services; the key to successful local development. The emphasis needs to be placed on adopting a suitable process to generate that infrastructure and service delivery.

The concept of an institutionally integrated development plan means that the local government concerned is responsible for ensuring the preparation of a spatially defined plan through which all 'players' - the private, including community sector; central government, including its parastatals; and local government itself, whether single or two tier - come to an agreement as to what is best for their community. This is where development (i.e. investment recommendations) is - or should be - allocated equitably, so that poorer localities and groups get more, in order to bring them to a level of equality (at minimum) in terms of the MDGs. Each organization, including local government, then prepares its strategy and budget (its investment decisions) for the things it is directly responsible for implementing, to ensure the provision of infrastructure and resulting services, economically, efficiently and effectively. This idea can be illustrated in Figure 1. 
Figure 1: Integrated development planning and budgeting

\begin{tabular}{|c|c|c|c|c|}
\hline \multicolumn{5}{|c|}{$\begin{array}{c}\text { Integrated district development plan } \\
\text { (inter-organisational and spatially defined) } \\
\text { Equitable allocation of development proposals }\end{array}$} \\
\hline Private sector & \multicolumn{2}{|c|}{ Local government } & \multicolumn{2}{|c|}{ Central government } \\
\hline \begin{tabular}{l|l} 
Communities/ & Business \\
NGOs &
\end{tabular} & Districts & Regions & $\begin{array}{l}\text { Deconcentrated } \\
\text { departments; } \\
\text { parastatals }\end{array}$ & $\begin{array}{l}\text { Ministry } \\
\text { HQs }\end{array}$ \\
\hline Spending decisions & \multicolumn{2}{|c|}{$\begin{array}{l}\text { Performance budget } \\
\text { Orqanisationally } \\
\text { specific } \\
\text { Development proposals } \\
\text { delivered economically, } \\
\text { efficiently and } \\
\text { effectively. }\end{array}$} & \multicolumn{2}{|c|}{ Performance budgets } \\
\hline
\end{tabular}

This diagram highlights four key points. First, is the inter-sectoral and therefore, interagency, spatially defined development plan. The idea is that all organizations, coordinated by local government, should contribute to both its formulation and its implementation; spending money to achieve things. Second, is the primary classification of the institutional environment; simply, the private/community sector, local government and central government. Third, this classification is broken down to one more level; in essence the spending organizations. Finally is the simple categorization of that spending; for the private sector, its individual spending decisions; for government, through budgets.

The point is to recognise where equitable allocations will be the primary concern; in development planning. Economic, efficient and effective delivery is through an organisation's strategy and budget (its performance budget). That is to say, we are allocating proposals spatially (for infrastructure and services) unequally, in order to bring the more deprived localities to a point of reasonable equality; the heart of equitable allocations. Such equality is judged through the prism of the MDGs. 
The allocated proposals are then delivered economically, efficiently and effectively through the organisationally specific performance budget. The assumption and practicality is that in any location, there are many players (many funders) in the local development process.

\section{Conclusion}

This paper has presented the five main aspects of capacity building (see Table 1 above). It has argued that these must be seen as means to an end and not an end in themselves. The true goal is the 'binding address' of local government's (coordinated) development planning and (individual) strategy and budgeting. These are the foundations for delivering infrastructure and services; the key to successful local development. Without local development, through the empowerment of households and communities (however defined), there will never be sustainable socio-economic progress in the developing world. The local institutional development paradigm seeks to create that empowerment. Otherwise, why decentralise?

We should also recognise that overseas development aid (ODA) is never going to answer fully the seemingly intractable challenges in the developing world. For that, decisions made in the private and community sectors will be the key to ultimate success. The under-rated report Unleashing Entrepreneurship (UNDP 2004) was an attempt to present this very argument. Local government should therefore be a key not only to that desired empowerment, but also to creating the conditions (ensuring the provision of the essential external economies, such as passable roads, electricity, schools and clinics) that will allow local economies to flourish. Thus, as Figure 1 illustrates, local government should be seen as part of a wider institutional and investment (spending) framework that supports socio-economic development.

In a public meeting with local citizen and business leaders in a Mozambique province about five years ago, this author asked: what are the two most fundamental things that UNCDF can achieve, in support of local development in this location?. The answer was simple to the point of brilliance: We need roads that are passable in the rainy seasons so that we can get our produce to market! We need funds to capitalize new and recapitalize old businesses shattered by the civil war! These were two fundamental blockages within the system that needed to be removed. Both could be within the purview of empowered local government. Building local government capacity in developing countries is thus a 
perennial concern, but we need better frameworks to make capacity building effective.

This paper has sought to show how those frameworks can be established.

\section{References}

McGill, R. 2009. A human rights approach to localising the MDGs through gender-equitable local development. Commonwealth Journal of Local Governance, (2009) Issue 4, pp 78-100. $<\underline{\text { http://epress.lib.uts.edu.au/ojs/index.php/cjlg/article/view/1357/1409> }}$

McGill, R. (Ed) 2006. Achieving results: performance budgeting in the least developed countries. United Nations Capital Development Fund, New York (2006), 234 pp. $<$ http://www.uncdf.org/english/local_development/documents_and_reports/thematic_papers/pb b/index.php>

McGill, R. 2006. 'Testing performance - a practical perspective on institutional reform', International Journal of Public Sector Management, Vol. 19, No. 1, pp. 95-110.

McGill, R. 2001a. 'Performance budgeting', International Journal of Public Sector Management, Vol. 14, No. 5, pp. 376-390.

McGill, R. 2001b. 'Urban management checklist', Cities: International Journal of Urban Policy and Planning, Vol. 18, No. 5, pp. 347-354.

McGill, R. 1999. 'Civil service reform in Tanzania: Organisation and efficiency through process consulting', International Journal of Public Sector Management (1999), Vol. 12, No. 5, pp. 410-419.

McGill, R. 1998. ‘Urban management in developing countries’, Cities: International Journal of Urban Policy and Planning, Vol. 15, No. 6, pp. 463-471.

McGill, R. 1997 and 1996. Institutional development: a Third World city management perspective. St Martin's Press, New York, NY (Jan, 1997) and Macmillan Press, Basingstoke (Nov, 1996), 310 pp. Republished as City Management in Developing Countries: an Institutional Development Perspective. BookSurge (2007), 310 pp. <http://www.amazon.com/s/ref=nb_ss_b/1031657137-9313404?url=search alias\%3Dstripbooks\&fieldkeywords=ronald.mcgill\&Go. $x=12 \& G o . y=8>$

McGill, R. 1995a. 'Institutional development: a review of the concept', International Journal of Public Sector Management, Vol. 8, No. 2, pp. 63-79.

McGill, R. 1995b. 'Urban management performance: an assessment framework for Third World city managers’, Cities: International Journal of Urban Policy and Planning, Vol. 12, No. 5, pp. 337-351.

McGill, R. 1994a. 'Integrated urban management: an operational model for Third World city managers', Cities: International Journal of Urban Policy and Planning, Vol. 11, No. 1, pp. 3547.

McGill, R. 1994b. 'Institutional development and the notion of sustainability', International Journal of Public Sector Management, Vol. 7, No. 6, pp. 26-40.

McGill, R. 1993. 'Institution building for a Third World city council: some lessons from the practice', International Journal of Public Sector Management, Vol. 6, No. 5, pp. 24-33.

McGill, R. 1988. 'Planning for strategic performance in local government', Long Range Planning, Vol. 21, No. 55, pp. 77-84.

McGill, R. 1986. 'Policy and budgetary planning: continuous community planning', Local Government Policy Making, Vol. 13, pp. 17-25.

McGill, R. 1984. 'Evaluating organisational performance in public administration', Public Administration Bulletin, No. 46, pp. 15-38. 
McGill, R. 1979. 'Conservation measures as a basis for local plans: the experience of Cockermouth and Maryport', Journal of Environmental Management and Planning, Vol. 22, pp 52-59.

UNCDF 2008. Gender-equitable local development (GELD) programme. $<$ http://www.uncdf.org/search/index.php?cx=016494082687074386866\%3Awcudhgu3uo\&cof=FORID\%3A10\&ie=UTF-8\&q=GELD\&sa=Go\#908>

UNDP 2004. Unleashing entrepreneurship; making business work for the poor. <http://www.undp.org/cpsd/report/index.html $>$ 